\title{
Review Article \\ Chlorophyll Extraction from Microalgae: A Review on the Process Engineering Aspects
}

\author{
Aris Hosikian, Su Lim, Ronald Halim, and Michael K. Danquah \\ Bio Engineering Laboratory (BEL), Department of Chemical Engineering, Monash University, Victoria 3800, Australia \\ Correspondence should be addressed to Ronald Halim, ronald.halim@eng.monash.edu.au \\ Received 1 February 2010; Accepted 30 March 2010 \\ Academic Editor: Ravichandra Potumarthi \\ Copyright () 2010 Aris Hosikian et al. This is an open access article distributed under the Creative Commons Attribution License, \\ which permits unrestricted use, distribution, and reproduction in any medium, provided the original work is properly cited.
}

Chlorophyll is an essential compound in many everyday products. It is used not only as an additive in pharmaceutical and cosmetic products but also as a natural food colouring agent. Additionally, it has antioxidant and antimutagenic properties. This review discusses the process engineering of chlorophyll extraction from microalgae. Different chlorophyll extraction methods and chlorophyll purification techniques are evaluated. Our preliminary analysis suggests supercritical fluid extraction to be superior to organic solvent extraction. When compared to spectroscopic technique, high performance liquid chromatography was shown to be more accurate and sensitive for chlorophyll analysis. Finally, through $\mathrm{CO}_{2}$ capture and wastewater treatment, microalgae cultivation process was shown to have strong potential for mitigation of environmental impacts.

\section{Background}

Microalgae are microscopic unicellular organisms capable to convert solar energy to chemical energy via photosynthesis. They contain numerous bioactive compounds that can be harnessed for commercial use. Marine microalgae in particular have unique biochemical characteristics not found in higher plants [1]. Microalgae are usually cultivated in open ponds or photobioreactors. The cultivation process requires carbon dioxide, light, water and other nutrients which facilitate the photosynthetic process. Microalgal cultivation captures greenhouse gas $\mathrm{CO}_{2}$ while simultaneously produces biomass containing high-value consumer products.

Chlorophyll is one of the valuable bioactive compounds that can be extracted from microalgal biomass. It is used as a natural food colouring agent and has antioxidant as well as antimutagenic properties. The process of extracting chlorophyll from marine microalgae begins with dewatering and desalting the highly dilute microalgal culture (biomass concentration $=0.1-1 \% \mathrm{w} / \mathrm{v})$. Chlorophyll is then extracted from the dried biomass by organic solvent extraction or supercritical fluid extraction. This process is followed by a fractionation step to separate the chlorophyll pigments and derivatives. Many studies have been carried out to optimize chlorophyll extraction and fractionation from microalgae. This review focuses on the entire chlorophyll production process beginning from microalgae cultivation to chlorophyll fractionation and purification.

1.1. Chlorophyll Classification. There are two main types of chlorophyll, chlorophyll $a$ and chlorophyll $b$. However, exposure of chlorophyll molecules to weak acids, oxygen or light accelerated their oxidation and resulted in the formation of numerous degradation products $[2,4,5]$. Figures 1, 2, and 3 shows the structures of the chlorophyll compounds. The skeleton of chlorophyll molecule is the porphyrin macrocycle, which comprises of four pyrrole rings $[6,7]$. An attachment of a single isocyclic ring to one of the pyrrole rings gives rise to the phorbin structure [6]. Each pyrrole ring contains four carbon atoms and one nitrogen atom. All of the nitrogen atoms face inward creating a central hole where an $\mathrm{Mg}^{2+}$ metal ion easily binds [7]. In chlorophyll $b$, the methyl group in ring II of chlorophyll $a$ is replaced by a formyl group $[5,7]$. This structural difference results in chlorophyll $a$ being a blue/green pigment with maximum absorbance from 660 to $665 \mathrm{~nm}$ and chlorophyll $b$ being a green/yellow with maximum absorbance from 642 to $652 \mathrm{~nm}$ [2]. 


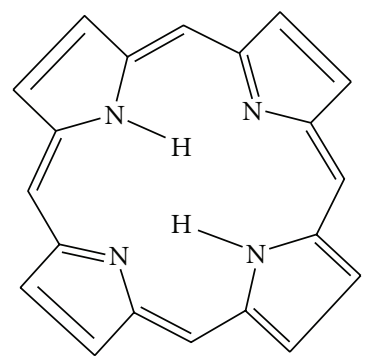

(a)

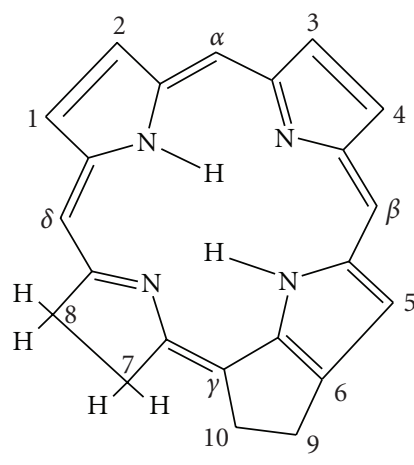

(b)

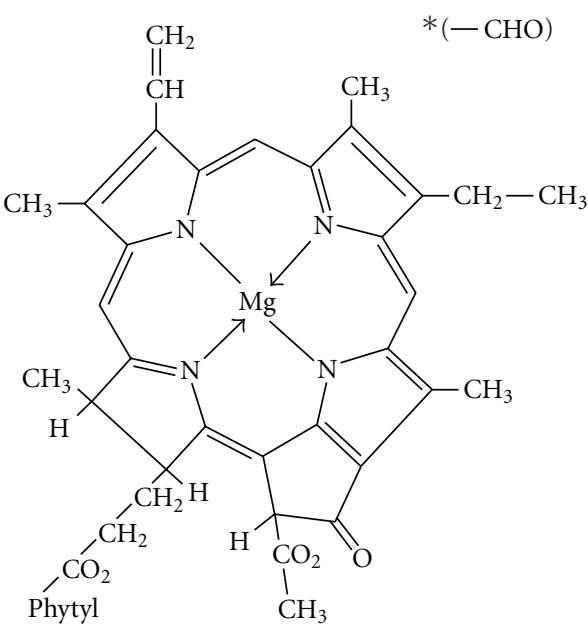

(c)

FIGURE 1: Chemical structures of chlorophyll and its constituents, extracted from [2]. (a) porphyrin macrocycle. (b) phorbin. (c) chlorophyll $a$, chlorophyll $b$ is a variant with the methyl group in position 3 being replaced by a formyl group.

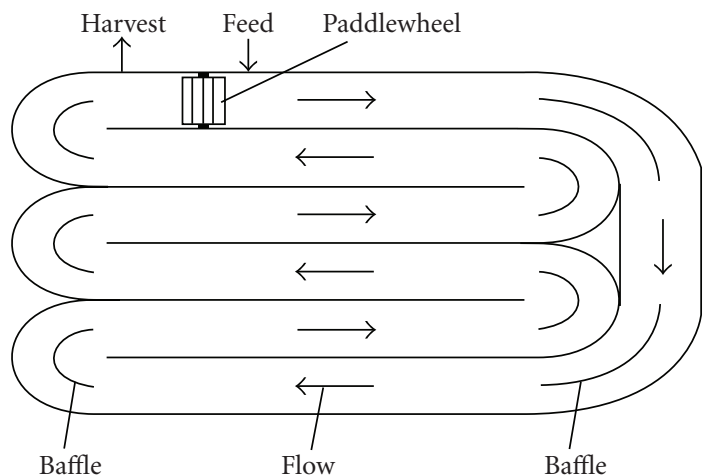

FIGURE 2: Raceway pond for open-air microalgae cultivation, extracted from [3].

1.2. Uses of Chlorophyll. Chlorophyll is present abundantly in nature and, due to its critical "light harvesting" role in photosynthesis, is vital to the survival of both the plant and animal kingdoms [6]. Chlorophyll selectively absorbs light in the red and blue regions and therefore emits a green colour. Photosynthesis is a process which uses this harvested light energy together with water and carbon dioxide to produce oxygen and carbohydrates; as such, it converts solar energy into chemical energy. The products from this chemical process reflect its significance, with carbohydrates being the primary building block for plants and oxygen being necessary for the survival of animal kingdom [6]. The importance of photosynthesis for life on earth is further highlighted by plants forming the basis of all food chains. Chlorophyll is a compound that is decomposed and reproduced continuously in significant amounts both terrestrially and in the oceans. It is estimated that 1.2 billion tons of chlorophyll are produced annually in the planet [6].

Chlorophyll is used as a colouring agent due to its selective absorbance of light of certain wavelengths and its consequent green colour. Changes in market demands and legislation have resulted in the requirement of natural colouring agents to be used in food products in preference to artificial colourings [8]. Colouring is essential for both consumers and manufacturers, as many foods lose their original colours due to chemical processes they undergo. Consumers demand products of original appearance, while manufacturers desire uniformity for all products $[8,9]$. Chlorophyll in plants is confined in chloroplasts where it is not only complexed with phospholipids, polypeptides and tocopherols but also protected by a hydrophobic membrane [6]. When chlorophyll is removed from this protective environment, its magnesium ion becomes unstable and may easily be displaced by a weak acid. In order to overcome this problem, the magnesium ion is often substituted with a copper ion to form a highly stable blue/green complex $[6,9]$.

Although chlorophyll is a natural food colouring agent, there are disadvantages associated with its use. Its pigment content is not precisely known and it tends to be unstable under the different $\mathrm{pH}$ conditions of the foods to which it is added. Additionally, it is more expensive than artificial colourings [8] and it must undergo a chemical modification by replacing the magnesium centre with a copper ion in order to improve its stability as a food colouring agent. Since the copper complex is not absorbed by the body and is removed in its entirety as an excretion product, it is considered to be safe and is permitted to be used in most countries as a food additive. However, the concentration of free ionisable copper in the colouring must be kept below 200 ppm under current regulations $[2,9]$.

Chlorophyll and its derivatives are also used widely in pharmaceutical products. Chlorophyll has been found to accelerate wound healing by more than $25 \%$ in some studies. Since chlorophyll stimulates tissue growth, it prevents the advancement of bacteria and speeds up the wound healing process $[10,11]$. Chlorophyll is similar in chemical structure to haemoglobin and, as such, is predicted to stimulate tissue 


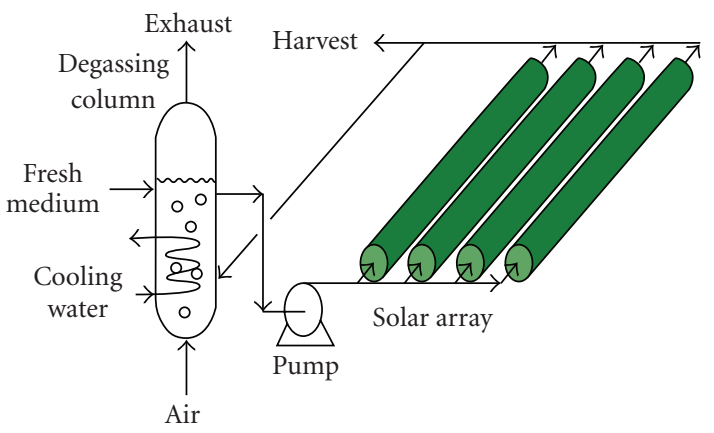

(a)

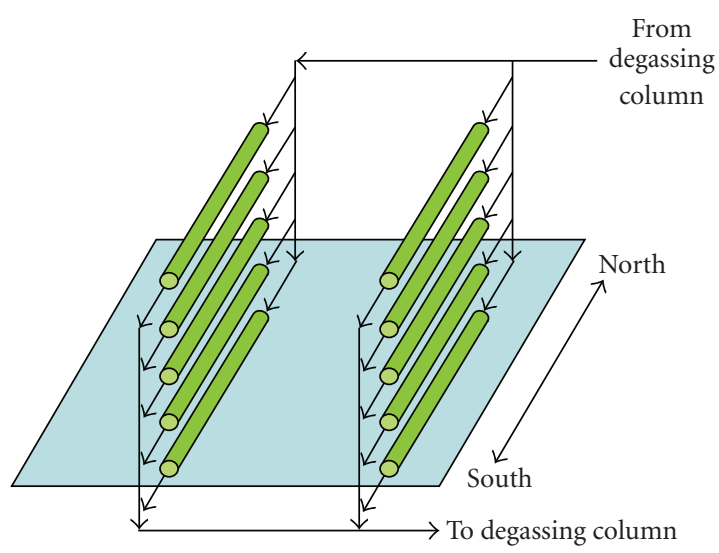

(b)

FIGURE 3: Different configurations of tubular photobioreactors, extracted from [3]. (a) parallel run horizontal tubes. (b) fence-like tubular array.

growth in a similar fashion through the facilitation of a rapid carbon dioxide and oxygen interchange [12]. Because of this property, chlorophyll is used not only in the treatment of ulcers and oral sepsis but also in proctology.

Chronic ulcer is a significant health problem in society, with lengthy periods required for its treatment [13]. Chlorophyll's ability to increase the rate of healing is a breakthrough for ulcer sufferers. The application of ointments containing chlorophyll derivatives was found not only to eliminate pain after several days but also to improve the appearance of the affected tissues [13]. The discharge from the ulcer and its characteristic odour also improved significantly after a few days of chlorophyll treatment [13].

The same properties which make chlorophyll a key compound in the treatment of ulcers also make it vital in the treatment of post-operative wounds from rectal surgery. When proctologists remove large areas of tissue, healing can be difficult and the area of the removed tissue tends to be painful [12]. The stimulation of cells in the host and the consequent acceleration in the tissue formation upon chlorophyll application increase the rate of healing in many cases by $25 \%$ [12]. Additionally, chlorophyll was found to remove odours from the wound after a few applications [12]. Its non-toxic nature, antibacterial property and deodorising function make chlorophyll a key product in the treatment of oral sepsis [14].

Chlorophyll $a$ and its derivatives also have profound antioxidant properties [15]. Chlorophyll derivatives such as pheophorbide $b$ and pheophytin b have always been known as strong antioxidants. However, these derivatives exist in very low concentrations in fruits and vegetables [15].

Fruit and vegetable consumption has been associated with decreasing the risks of cancer. Phytochemicals present in these foods, particularly chlorophyll and its derivatives, have been suggested to play a key role in cancer prevention due to their high displays of antioxidant and antimutagenic activities $[15,16]$. The most significant activity of chlorophyll derivatives in the prevention of cancer is the trapping of mutagens in the gastrointestinal tract [16].

\section{Capturing $\mathrm{CO}_{2}$ with Microalgae}

Over the past several decades, global warming has become a serious threat to both humans and nature [17]. The increase of Earth's surface temperature can bring about extreme weather occurrences, rise in sea levels, extinction of species, retreat of glaciers and many other calamities. The rise in global temperature is attributed to the high amount of carbon dioxide $\left(\mathrm{CO}_{2}\right)$ gases in the atmosphere $[18,19] . \mathrm{CO}_{2}$ is emitted from the burning of fossil fuels for electricity, transport, and industrial processes $[17,18,20]$. Due to the serious threat of global warming, the Kyoto Protocol in 1997 proposed a reduction of greenhouse gases by $5.2 \%$ based on the emissions in 1990.

Since then, many $\mathrm{CO}_{2}$ mitigation options have been considered to meet the proposed target [17]. The various strategies suggested can be classified into two main categories: chemical reaction-based approaches and biological mitigation. Chemical reaction-based strategy captures $\mathrm{CO}_{2}$ by reaction with other chemical compounds before the $\mathrm{CO}_{2}$ is released to the atmosphere. The disadvantage of this method is that the chemical reactions are very energyintensive and costly. Furthermore, both $\mathrm{CO}_{2}$ and the wasted chemical compounds need to be disposed of. On the other hand, biological mitigation is deemed to be more favourable as it not only captures $\mathrm{CO}_{2}$ but also generates energy through photosynthesis [19]. This method will be much simpler than physical $\mathrm{CO}_{2}$ sequestration [21].

Photosynthesis is carried out by all plants and any photosynthetic microorganisms. Even though the use of plants to capture $\mathrm{CO}_{2}$ is viable, it is by no means efficient owing to its slow growth rate. On the other hand, microalgae as photosynthetic microorganisms are able to capture solar energy and $\mathrm{CO}_{2}$ with an efficiency of 10 to 50 times greater than that of higher plants [19]. Microalgae includes both prokaryotic cyanobacteria and eukaryotic unicellular algae [17]. The structural and functional simplicity of these microorganisms makes them a better choice for research purposes than any other terrestrial plants [22]. In addition, 
microalgae have rapid growth rates and higher productivities than any other plant systems. Microalgae can also grow in variable environmental conditions [19,20,23].

Apart from $\mathrm{CO}_{2}$ and sunlight, microalgae also need nutrients, trace metals and water to grow [24]. In short, biomass from microalgae cultivation is produced based on the following reaction:

$$
\mathrm{CO}_{2}+\mathrm{H}_{2} \mathrm{O}+\text { nutrients }+ \text { light energy } \longrightarrow \text { biomass }+\mathrm{O}_{2}
$$

see [25].

Unlike plants, microalgae can be cultivated with waste or brackish water despite its abundance of heavy metals and pathogens. The nitrogen and phosphorous in waste water can be directly used by the microalgae as nutrients. Hence, use of chemicals and freshwater needed for algal cultivation can be reduced. It also means that it is entirely feasible to incorporate wastewater treatment process with microalgal cultivation $[17,19]$.

There are over 30,000 species of microalgae in existence on the Earth and they contain a variety of chemicals that have commercial values [26]. Thus, the biomass produced from microalgal cultivation has numerous uses [17]: (1) a source of biofuels (biodiesel and bioethanol); (2) a nutritional supplement for humans in the form of tablets, capsules, powders and liquids; (3) a natural food colorant; (4) a natural food source for many aquacultural species; (5) a nutritional supplement for animals to improve immune response and fertility; (6) for cosmetic supplements; (7) a source of highvalue functional ingredients like polyunsaturated fatty acids, $\omega$-3 fatty acids, pigments, and stable isotope biochemicals; (8) a raw material for the formation of 'biochar' through pyrolysis that can be used as biofertiliser and for carbon sequestration [17, 27]; (9) a source of renewable hydrogen [28].

Microalgae can capture $\mathrm{CO}_{2}$ from the atmosphere, from industrial gases (i.e., power plant flue gases) and in the form of soluble carbonates (i.e., $\mathrm{Na}_{2} \mathrm{CO}_{3}$ and $\mathrm{NaHCO}_{3}$ ) $[19,20]$. Generally, $\mathrm{CO}_{2}$ concentration from power plants is higher than the atmosphere. The low $\mathrm{CO}_{2}$ concentration in the atmosphere can slow down the growth of microalgae due to mass transfer limitation. Efficiency of $\mathrm{CO}_{2}$ capture by microalgae increases with power plant flue gases that have up to $15 \%$ of $\mathrm{CO}_{2}$ [19] and studies have shown that microalgal species (such as Scenedesmus sp. and Chlorella sp.) can tolerate $10 \%$ to $30 \% \mathrm{CO}_{2}$ in its gas supply [29]. Therefore microalgal cultivation can be synergistically located adjacent to a power plant where the $\mathrm{CO}_{2}$ emitted from such a plant can be conveniently sequestered by the algae as a source of their nutrients [17].

\section{Microalgal Cultivation System}

There are two main microalgal large-scale cultivation systems: (1) open air-system and (2) photobioreactors [30]. The selection of a cultivation system depends on several factors: the type and the biology of the algal species, the availability of sunlight, the cost of land, the water supply, the availability of nutrients, the desired final product, the climate conditions and the supply of $\mathrm{CO}_{2}[25,30]$. The amount of nutrients and certain metals (i.e., iron and magnesium) must be optimum as they are important for the growth of microalgae and $\mathrm{CO}_{2}$ fixation efficiency [19]. Research from an outdoor mass cultivation in New Mexico showed that with the right levels of nutrients, $\mathrm{CO}_{2}$ fixation by microalgae could be increased [23]. A welldesigned cultivation system can improve the effectiveness of $\mathrm{CO}_{2}$ capture by microalgae [19]. Another important factor when deciding on a cultivation system is the likelihood of contamination by other microorganisms [19]. For example, algal species like Chlorella, Dunaliella, and Spirulina can grow only in specific environments, hence are not likely to be contaminated by other microalgae when cultivated in an openair system. In contrast, some marine microalgae such as Tetraselmis, Skeletonem, and Isochrysis are susceptible to foreign invasion and must be grown in closed photobioreactors [30].

3.1. Open-Air System. There are many kinds of open-air systems with each having its own set of advantages and disadvantages. The four common types of open-air systems are shallow big ponds, tanks, circular ponds, and raceway ponds [30]. Open-air systems are less complex to construct and operate than photobioreactors [31]. They are considered as low cost methods to cultivate microalgae if compared to closed systems [19]. Nevertheless, open-air systems have many disadvantages, including diffusion of $\mathrm{CO}_{2}$ back to the environment, requirement for a large area of land, evaporative water losses, and poor light utilization [31]. Besides that, open systems are exposed to many elements in the atmosphere. Hence, they give low biomass yields as it is difficult to control the culture conditions. The depth of the ponds also presents a problem. It needs to be shallow enough for the sunlight to reach the microalgal cells and, at the same time, deep enough for sufficient mixing. Thus, the maximum biomass that can be achieved from most microalgae is roughly between 0.1 to $0.5 \mathrm{~g}$ dry weight/L culture [30].

Among the many types of open-air systems, the most common design is the raceway pond as shown in Figure 2 [19]. The raceway pond is made up of a closed loop recirculation channel that includes a paddle wheel. The paddle wheel provides the circulation and the mixing, while the baffles placed in the channel guide the flow. To ensure that the light reaches the microalgal cells, the raceway pond is only about $0.3 \mathrm{~m}$ in depth. This design has been around since the 1950s. The raceways ponds are made from concrete or compacted earth that can be lined with plastics [3]. The continuous mixing that occurs within the pond enables high growth rate and minimises contamination risk by foreign microalgae [30].

Even though this open-air cultivation method is not ideal, there are several companies using the design, such as Aquaflow Bionomics and Live Fuels based respectively in New Zealand and the United States. Both of these companies are using alternative techniques to deal with the presence of unwanted microorganisms [32]. 
TABLE 1: Previous studies on organic solvent extraction of microalgal chlorophyll.

\begin{tabular}{|c|c|c|c|c|}
\hline Study & Algae species & Solvent & Cell disruption & Key results \\
\hline Jeffrey et al. [4] & Phytoplankton & $\begin{array}{l}\text { Methanol } \\
(90 \%), \text { ethanol } \\
(90 \%) \text {, ethanol } \\
(100 \%), \text { DMF }\end{array}$ & All & $\begin{array}{l}\text { DMF is superior to all the other solvents used and cell } \\
\text { lysis improves extraction in all cases. }\end{array}$ \\
\hline $\begin{array}{l}\text { Macías-Sánchez } \\
\text { et al. [33] }\end{array}$ & Dunaliella Salina & DMF Methanol & Ultrasound & DMF was found to be more efficient methanol. \\
\hline & $\begin{array}{l}\text { Scenedesmus } \\
\text { quadricauda, }\end{array}$ & $\begin{array}{l}\text { Ethanol (95\%), } \\
\text { methanol, }\end{array}$ & $\begin{array}{l}\text { Homogenisation, } \\
\text { sonication, boiling }\end{array}$ & $\begin{array}{l}\text { (1) Methanol and } 95 \% \text { ethanol were superior to } 90 \% \\
\text { acetone. }\end{array}$ \\
\hline $\begin{array}{l}\text { Sartory \& } \\
\text { Grobbelaar [34] }\end{array}$ & $\begin{array}{l}\text { Selenastrum } \\
\text { capricornutum, } \\
\text { Microcystysis } \\
\text { aeruginosa }\end{array}$ & acetone $(90 \%)$ & & $\begin{array}{l}\text { (2) Boiling the algae in either methanol or } 95 \% \text { ethanol } \\
\text { for } 5 \text { minutes and allowing extraction for } 24 \text { hours } \\
\text { resulted in the complete extraction of pigments without } \\
\text { any formation of degradation products. }\end{array}$ \\
\hline \multirow{3}{*}{$\begin{array}{l}\text { Schuman et al. } \\
\text { [35] }\end{array}$} & \multirow[t]{3}{*}{$\begin{array}{l}\text { Stichococcus, } \\
\text { Chlorella }\end{array}$} & \multirow[t]{3}{*}{$\begin{array}{l}\text { Acetone, } \\
\text { DMF }\end{array}$} & \multirow[t]{3}{*}{$\begin{array}{l}\text { Grinding, } \\
\text { Ultrasoun, } \\
\text { bead beater }\end{array}$} & $\begin{array}{l}\text { (1) DMF was found to be the most efficient solvent. } \\
\text { (2) Acetone extracted } 56-100 \% \text { of the amount of } \\
\text { chlorophyll } a \text { extracted by DMF. }\end{array}$ \\
\hline & & & & (3) DMF does not require cell disruption. \\
\hline & & & & (4) Freeze drying before analysis aids extraction \\
\hline $\begin{array}{l}\text { Simon \& } \\
\text { Helliwell [36] }\end{array}$ & $\begin{array}{l}\text { Freshwater algae } \\
\text { Selenastrum obliquus }\end{array}$ & $\begin{array}{l}\text { Methanol and } \\
\text { acetone }\end{array}$ & $\begin{array}{l}\text { Probe sonication, } \\
\text { bath sonication, } \\
\text { tissue grinding, } \\
\text { mortar and pestle }\end{array}$ & $\begin{array}{l}\text { Under sonication, methanol removed } 3 \mathrm{x} \text { more pigment } \\
\text { than acetone. Under tissue grinding, methanol } \\
\text { removed } 20 \% \text { more than acetone. }\end{array}$ \\
\hline
\end{tabular}

3.2. Photobioreactor System. The photobioreactor system maximises photosynthesis by circulating the microalgal cells, nutrients, and $\mathrm{CO}_{2}$ in a narrow enclosed transparent vessel exposed to ample illumination [32]. Its high-surface-areato-volume ratio enables optimal light utilisation leading to higher biomass productivity. Furthermore, the photobioreactor's closed design facilitates high sterility, robust control of temperature, and good management of culture conditions. All these advantages allow the photobioreactor system to culture a variety of microalgal species without any contamination and to produce a high quality biomass. The photobioreactors are also continuously well-mixed to improve gas diffusion into the microalgal cells. Even though the photobioreactor system gives control over most cultivation parameters and achieves a higher $\mathrm{CO}_{2}$ fixation rate than open-air system, it requires large amount of energy for its operation and construction $[19,30]$.

The photobioreactor system comes in several designs like flat-plate, tubular, bubble-sparged vertical column, and airlift. Of those designs, tubular photobioreactors are the most popular $[19,31]$. Table 2 shows the comparison between raceway ponds and tubular photobioreactors. Tubular photobioreactors is made up of an array of clear straight tubes. These tubes are made of either glass or plastic and are usually less than $0.1 \mathrm{~m}$ in diameter in order to allow for light penetration. The tubes are arranged either horizontally where they are placed parallel to each other flat on the ground or vertically where they are configured to form fence-like structures. Figure 3 shows the two different configurations of tubular photobioreactors [3].
Flat-plate photobioreactors are frequently used for its large illumination surface area. Like the tubular design, flatplate photobioreactors are also made out of transparent materials for maximum penetration of sunlight. This design can also achieve high $\mathrm{CO}_{2}$ fixation efficiency and mass cultivation of microalgae. In fact, there is less build-up of oxygen in the flat-plate design compare to the tubular design. However, the design suffers from the following drawbacks: (1) difficulty in controlling culture temperatures; (2) scaleup requires more compartments and support materials; (3) stronger hydrodynamic stress on microalgal cultures [31].

Apart from the four primary designs, there are other types of photobioreactor systems that are currently used. The basics of the systems are the same with some modficiations to maximise the efficiency. One such example is a $450 \mathrm{ft}$ long by $50 \mathrm{ft}$ wide photobioreactor made up of twin transparent plastic algal waterbeds patented by a company called A2BE Carbon Capture LLC. Another company, Green Shift Corporation based in New York has produced a pilotscale photobioreactor that is incorporated with an ethanol producing facility to capture the $\mathrm{CO}_{2}$ emitted from power plants [32].

\section{Chlorophyll Extraction Methods}

4.1. Organic Solvent Extraction. In order to quantify the amount of chlorophyll in a particular species, the intracellular chlorophyll must first be extracted. The traditional method that has been employed is organic solvent extraction $[4,36]$. The extraction process involves the organic solvent 
TABLE 2: Comparison between microalgal cultivation systems [19].

\begin{tabular}{lcc}
\hline System & Raceway ponds & Tubular photobioreactors \\
\hline Light efficiency & Fairly good & Excellent \\
Temperature control & None & Excellent \\
Gas transfer & Poor & Low - high \\
Oxygen production & Low & High \\
Accumulation & Low & Low - high \\
Hydrodynamic stress on algae & Difficult & Easy \\
Species control & None & Achievable \\
Sterility & Low & High \\
Cost to scale-up & Low & High \\
Volumetric productivity & High & Low \\
\hline
\end{tabular}

penetrating through the cell membrane and dissolving the lipids as well as the lipoproteins of chloroplast membranes [4]. It has been found that cell disruption, achieved through grinding, homogenisation, ultrasound or sonication, significantly improves the effectiveness of chlorophyll extraction using organic solvents $[4,33,34,36]$. Simon and Helliwell [36] found that, without cell disruption, only a quarter of the potential chlorophyll $a$ was able to be extracted by an optimal method. In addition to cell disruption, there are other parameters which affect the efficiency of organic solvent extraction, including the storage conditions of the filtered microalgae prior to the analysis, the organic solvents used, the duration of the extraction and the number of extraction steps employed in the analysis $[4,34,35]$. Since chlorophyll is highly reactive, the yield of a particular extraction procedure is also affected by the formation of degradation products. Degradation products of chlorophyll are formed when their molecules are exposed to excess light, oxygen/air, high temperatures and acidic or basic conditions $[4,5]$.

Table 1 shows previous studies on organic solvent extraction of microalgal chlorophyll. Simon and Helliwell [36], Sartory and Grobbelaar [34], and Jeffrey et al. [4] found methanol and ethanol to be superior extraction solvents to acetone. Simon and Helliwell [36] conducted their sonication-assisted chlorophyll extractions in an ice bath and in dark conditions to prevent degradation products from forming. They found that, with sonication, methanol removed three times more pigment than 90\% acetone. Additionally, when tissue grinding was used, methanol removed 20\% more pigment than $90 \%$ acetone. Sartory and Grobbelaar [34] similarly found that 90\% acetone was an inefficient organic solvent compared to methanol or $95 \%$ ethanol. However, it has been shown that the use of methanol as an extraction solvent resulted in an unstable solution and lead to the formation of chlorophyll $a$ degradation products $[4,37]$. Although $100 \%$ acetone was found not to yield the highest amount of chlorophyll from any particular species, its use as an extracting solvent strongly inhibited the formation of degradation products [4]. In studies carried out by Jeffrey et al. [4] and Macías-Sánchez et al. [33], dimethyl formamide (DMF) was found to be a superior extraction solvent to methanol, 90\% ethanol, 100\% ethanol and 90\% acetone.
Extraction using DMF did not require cell disruption as pigments were completely extracted after a few steps of soaking. Additionally, the pigments remained stable for up to twenty days when stored in the dark at $5^{\circ} \mathrm{C}[4,35]$. However, DMF toxic nature decreased its appeal as an efficient solvent [4]. It was also found that storage of the microalgae at low temperatures after filtration $\left(-18^{\circ} \mathrm{C}\right.$ or $\left.-20^{\circ} \mathrm{C}\right)$ assisted cell disruption and promoted the extraction of chlorophyll [4]. Schumann et al. [35] found freezing the biomass in liquid nitrogen followed by lyophilisation and then storage at $-18^{\circ} \mathrm{C}$ to be the optimal storage procedure.

Sartory and Grobbelaar [34] found the efficiency of chlorophyll extraction from fresh water microalgae to be optimal when the filtered microalgae and solution were refluxed at the solvent's boiling point. It was shown that boiling for 3 to 5 minutes in methanol or 95\% acetone prior to 24-hour extraction led to the complete isolation of chlorophyll $a$ without the formation of any degradation products. However when the mixture was subjected to temperatures of $100^{\circ} \mathrm{C}$, degradation products started to form [34]. Such findings are contradictory to the general assumption that chlorophyll degraded upon slight temperature elevation.

The amount of chlorophyll extracted from a particular algal species was found to be highly dependent on its growth stage. Microalgae extracted in the stationary growth phase were shown to have significantly higher amount of chlorophyll $a$ compared to the same species obtained in the logarithmic phase [35].

4.2. Supercritical Fluid Extraction (SFE). The use of organic solvents for lipophilic extraction posts a serious threat to the environment. The Montreal Protocol in 1987 proposed to restrict or to eliminate the manufacture and the use of ozone depleting solvents such as chlorofluorocarbons (CFCs). From then on, the Montreal Protocol has evolved and most solvents that are damaging to the environment have been restricted. As a result, more industries are looking into a new sustainable process that does not involve environmentally damaging solvents [38]. Supercritical fluid extraction (SFE) is a popular method to replace organic solvent extraction.

Supercritical fluid extraction was first introduced as an alternative extraction method in 1879 by Hannay and 
TABLE 3: Comparison between organic solvent extraction and $\mathrm{SCCO}_{2}$ extraction, modified from [40].

\begin{tabular}{lll}
\hline No. & Organic solvent extraction & $\mathrm{SCCO}_{2}$ extraction \\
\hline 1 & $\begin{array}{l}\text { Solvent presence is unavoidable. The amount of solvent } \\
\text { depends on the type of solvent used. Solvent removal requires } \\
\text { extra unit operations and increases operational cost. }\end{array}$ & $\mathrm{SCCO}_{2}$ extraction produces solvent-free extracts. \\
& $\begin{array}{l}\text { Heavy metal and inorganic salt contents are also unavoidable. } \\
\text { Their levels depend on the solvent, the method of solvent } \\
\text { recycling, the source of the raw material, and the materials used } \\
\text { to construct the contact parts of the machinery. }\end{array}$ & $\begin{array}{l}\text { Extract is completely free of heavy metals and } \\
\text { inorganic salts since they are not extractable by } \\
\text { the } \mathrm{SCCO}_{2} \text { even if they are present in the raw } \\
\text { material. No heavy metals are present in the } \mathrm{CO}_{2} \\
\text { extractant or the SFE system. }\end{array}$ \\
$\begin{array}{l}\text { Polar substances get dissolved along with the lipophilic } \\
\text { substances from the raw material due to poor selectivity of the } \\
\text { solvent. During solvent removal operations, these polar } \\
\text { substances may form polymers which lead to discoloration of } \\
\text { the extract. }\end{array}$ & $\begin{array}{l}\text { Due its nonpolar nature, SCCO } \mathrm{S}_{2} \text { will not extract } \\
\text { any polar substance. }\end{array}$ &
\end{tabular}

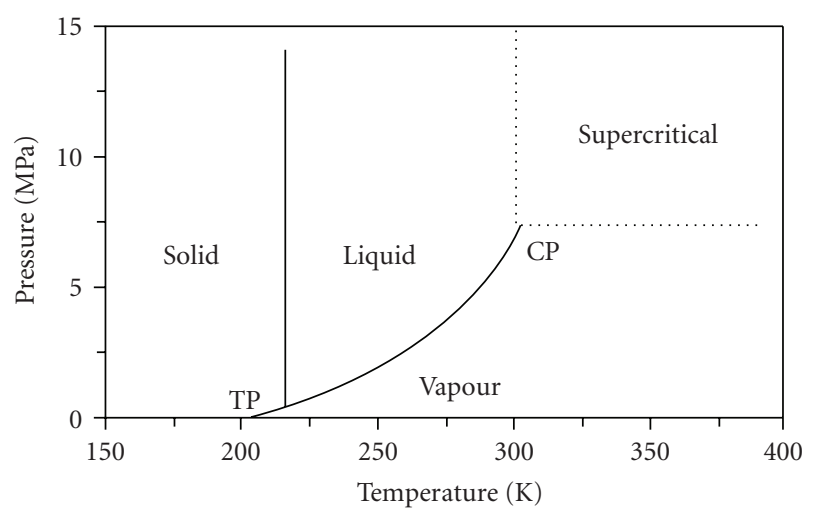

FIgURE 4: P-T phase diagram for carbon dioxide [42].

Hogarth. However, it was not until around 1960 that this extraction method started to be thoroughly investigated [39]. SFE has many advantages over organic solvent extraction. One of the major advantages is the high purity of the extract. In addition to requiring less processing steps, SFE is significantly safer than organic solvent extraction and can be operated at moderate temperatures to minimize extract degradation. Table 3 shows the comparison between the two extraction methods [40].

The supercritical state is achieved when a substance is exposed to conditions exceeding its critical temperature $\left(\mathrm{T}_{\mathrm{c}}\right)$ and pressure $\left(\mathrm{P}_{\mathrm{c}}\right)$. In this state, the substance has liquidlike densities with the viscosities of a gas. The solvent power of supercritical fluids is the highest for slightly polar or non-polar components and is lower for analytes with higher molecular weights. The fluid is easily removed from extract through expansion to atmospheric pressure [41].

$\mathrm{CO}_{2}$ is the most commonly used fluid for SFE as it is cheap, non-flammable, readily available, and somewhat inert. Figure 4 shows the phase diagram for $\mathrm{CO}_{2}$ with its supercritical region. The critical temperature and pressure of $\mathrm{CO}_{2}$ are $304.1 \mathrm{~K}$ and $7.38 \mathrm{MPa}$, respectively. The moderate $\mathrm{T}_{\mathrm{c}}$ of $\mathrm{CO}_{2}$ yields higher quality extracts because it avoids excessive heating which often leads to degradation. This allows for supercritical carbon dioxide $\left(\mathrm{SCCO}_{2}\right)$ to be used in

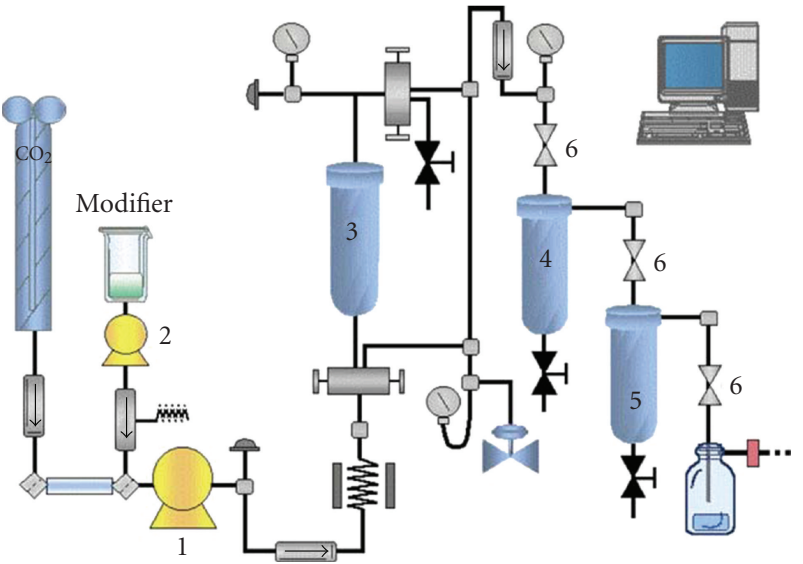

FIGURE 5: Schematic diagram of supercritical fluid extraction system, extracted from [45]. (1) $\mathrm{CO}_{2}$ pump, (2) modifier pump, (3) extraction cell, (4) fractionation cell I, (5) fractionation cell II, (6) valve.

the extraction of thermolabile compounds [42, 43]. $\mathrm{SCCO}_{2}$ is also preferred due to its high diffusivity and the ease in manipulating its solvent strength. This can be done by adding a substance or modifier which has volatility between the supercritical fluid and the analyte that is to be extracted. For example, the addition of a polar solvent like methanol or water to supercritical $\mathrm{CO}_{2}$ allows it to extract polar compounds $[39,42]$. Studies have shown that addition of ethanol to supercritical fluid increases the yield of lipids from Arthrospira maxima [44].

$\mathrm{SCCO}_{2}$ extraction is applicable in many different fields such as food and natural products extraction, environmental science and pharmaceuticals [39]. This review will focus on $\mathrm{SCCO}_{2}$ extraction of chlorophyll from microalgae. Chlorophyll is mainly used in food technology, so there are stringent regulations regarding its quality. By using $\mathrm{SCCO}_{2}$ extraction, a solvent-free highly pure extract can be achieved. Upon decompression, the supercritical $\mathrm{CO}_{2}$ is removed from the extract as it evaporates to the ambiance in its gaseous state [45]. 
TABLE 4: Previous studies on HPLC fractionation of chlorophylls extracted from phytoplanktons.

\begin{tabular}{|c|c|c|c|}
\hline $\begin{array}{l}\text { Study, } \\
\text { Chromatography }\end{array}$ & Mobile phase & $\begin{array}{l}\text { Stationary } \\
\text { phase }\end{array}$ & Key results \\
\hline \multirow{2}{*}{$\begin{array}{l}\text { Jeffrey [49], } \\
\text { TLC }\end{array}$} & $\begin{array}{l}\text { First dimension: } 0.8 \% \text { n-propanol in light } \\
\text { petroleum (by volume) }\end{array}$ & \multirow[t]{2}{*}{ Sucrose } & \multirow{2}{*}{$\begin{array}{l}\text { In this two dimensional chromatography, there } \\
\text { was complete separation of chlorophylls and } \\
\text { carotenoids. }\end{array}$} \\
\hline & $\begin{array}{l}\text { Second dimension: } 20 \% \text { chloroform in light } \\
\text { petroleum (by volume) }\end{array}$ & & \\
\hline \multirow{3}{*}{$\begin{array}{l}\text { Jeffrey et al. [4], } \\
\text { HPLC }\end{array}$} & $\begin{array}{l}90: 10(\mathrm{v} / \mathrm{v}) \text { methanol }: \text { acetone } \\
\text { for } 8 \mathrm{~min} \text { at a flow rate } 1 \mathrm{~mL} / \mathrm{min}\end{array}$ & \multirow{3}{*}{$\begin{array}{l}3 \mu \mathrm{m} \mathrm{C} 18 \\
\text { Pecosphere }\end{array}$} & \multirow{3}{*}{$\begin{array}{l}\text { This simple isocratic protocol was able to separate } \\
\text { only chlorophyll } a \text { from other pigments and } \\
\text { compounds. }\end{array}$} \\
\hline & Preinjection mix of sample & & \\
\hline & $3: 1$ (v/v) sample: $0.5 \mathrm{M}$ ammonium acetate & & \\
\hline \multirow{8}{*}{$\begin{array}{l}\text { Jeffrey et al. [4], } \\
\text { HPLC }\end{array}$} & $\begin{array}{l}\text { Solvent } A \text { is } 80: 20(\mathrm{v} / \mathrm{v}) \text { methanol: } 0.5 \mathrm{M} \\
\text { ammonium acetate }\end{array}$ & \multirow{8}{*}{$\begin{array}{l}3 \mu \mathrm{m} \mathrm{C} 18 \\
\text { Pecosphere }\end{array}$} & \multirow{8}{*}{$\begin{array}{l}\text { This step-isocratic protocol was found to } \\
\text { successfully separate the three chlorophylls ( } a, b \\
\text { and } c \text { ) and ten other derivative products. }\end{array}$} \\
\hline & Solvent B is $90: 10$ methanol: acetone & & \\
\hline & Elution order: & & \\
\hline & 0-3 min: solvent A & & \\
\hline & 3-17 min: solvent B & & \\
\hline & flow rates: $1 \mathrm{~mL} / \mathrm{min}$ & & \\
\hline & Pre-injection mix of samplee & & \\
\hline & $3: 1(\mathrm{v} / \mathrm{v})$ sample: $0.5 \mathrm{M}$ ammonium acetat & & \\
\hline \multirow{9}{*}{$\begin{array}{l}\text { Jeffrey et al. [4], } \\
\text { HPLC }\end{array}$} & $\begin{array}{l}\text { Solvent } A \text { is } 80: 20(\mathrm{v} / \mathrm{v}) \text { methanol: } 0.5 \mathrm{M} \\
\text { ammonium acetate }\end{array}$ & \multirow{9}{*}{$\begin{array}{l}3 \mu \mathrm{m} \mathrm{C} 18 \\
\text { Pecosphere }\end{array}$} & \multirow{9}{*}{$\begin{array}{l}\text { This ternary gradient protocol was found to } \\
\text { separate over } 50 \text { pigments. The resolution of this } \\
\text { protocol is higher than that of Wright and Shearer } \\
\text { [51]. Additionally no ion pairing reagent is } \\
\text { required, as in Mantoura and Llewellyn [37]. }\end{array}$} \\
\hline & Solvent B is $90: 10(\mathrm{v} / \mathrm{v})$ acetonitrile: water & & \\
\hline & Solvent C is ethyl acetate & & \\
\hline & Elution order: & & \\
\hline & 0-4 min: linear gradient from $100 \%$ A to $100 \% \mathrm{~B}$ & & \\
\hline & 4-18 min: linear gradient to $20 \% \mathrm{~B}$ and $80 \% \mathrm{C}$ & & \\
\hline & $18-21 \mathrm{~min}$ : linear gradient to $100 \% \mathrm{~B}$ & & \\
\hline & $21-24$ min: linear gradient to $100 \% \mathrm{~A}$ & & \\
\hline & $24-29$ min: isocratic flow of $100 \% \mathrm{~A}$ & & \\
\hline
\end{tabular}

Three different solvent systems were experimented.

Solvent system 1 (modified Bauer solvents): First Silica Gel dimension is benzene: petroleum ether: acetone

Lynn Co and Schanderl [52], TLC $(10: 2.5: 2 \mathrm{v} / \mathrm{v} / \mathrm{v})$

Second dimension is benzene: petroleum ether: acetone: methanol $(10: 2.5: 1: 0.25 \mathrm{v} / \mathrm{v} / \mathrm{v})$

Solvent system 2: First dimension is benzene: petroleum ether: acetone: methanol $(10: 2.5: 1: 0.25 \mathrm{v} / \mathrm{v} / \mathrm{v})$

Second dimension is petroleum ether: acetone: n-propanol $(8: 2: 0.5 \mathrm{v} / \mathrm{v} / \mathrm{v})$

Solvent system 3: First dimension is benzene: petroleum ether: acetone $(10: 2.5: 2 \mathrm{v} / \mathrm{v} / \mathrm{v})$ Second dimension is petroleum ether: acetone: n-propanol $(8: 2: 0.5 \mathrm{v} / \mathrm{v} / \mathrm{v})$

$30 \mathrm{~mL}$ of $1: 1(\mathrm{v} / \mathrm{v})$ diethyl ether : petroleum spirit
Glucose
Two dimensional chromatography was carried out on silica gel. Eight major pigments as well as eight to ten minor derivatives were successfully separated with these solvent systems.
Madgwick [50],

TLC
(1) One dimensional ascending thin layer chromatography was used.

(2) Spectrophotometric analysis was found to overestimate chlorophyll $c$ by up to $22 \%$ and to underestimate chlorophyll $b$ by $10-20 \%$. Chlorophyll $a$ was, however, correctly quantified. 
TABle 4: Continued.

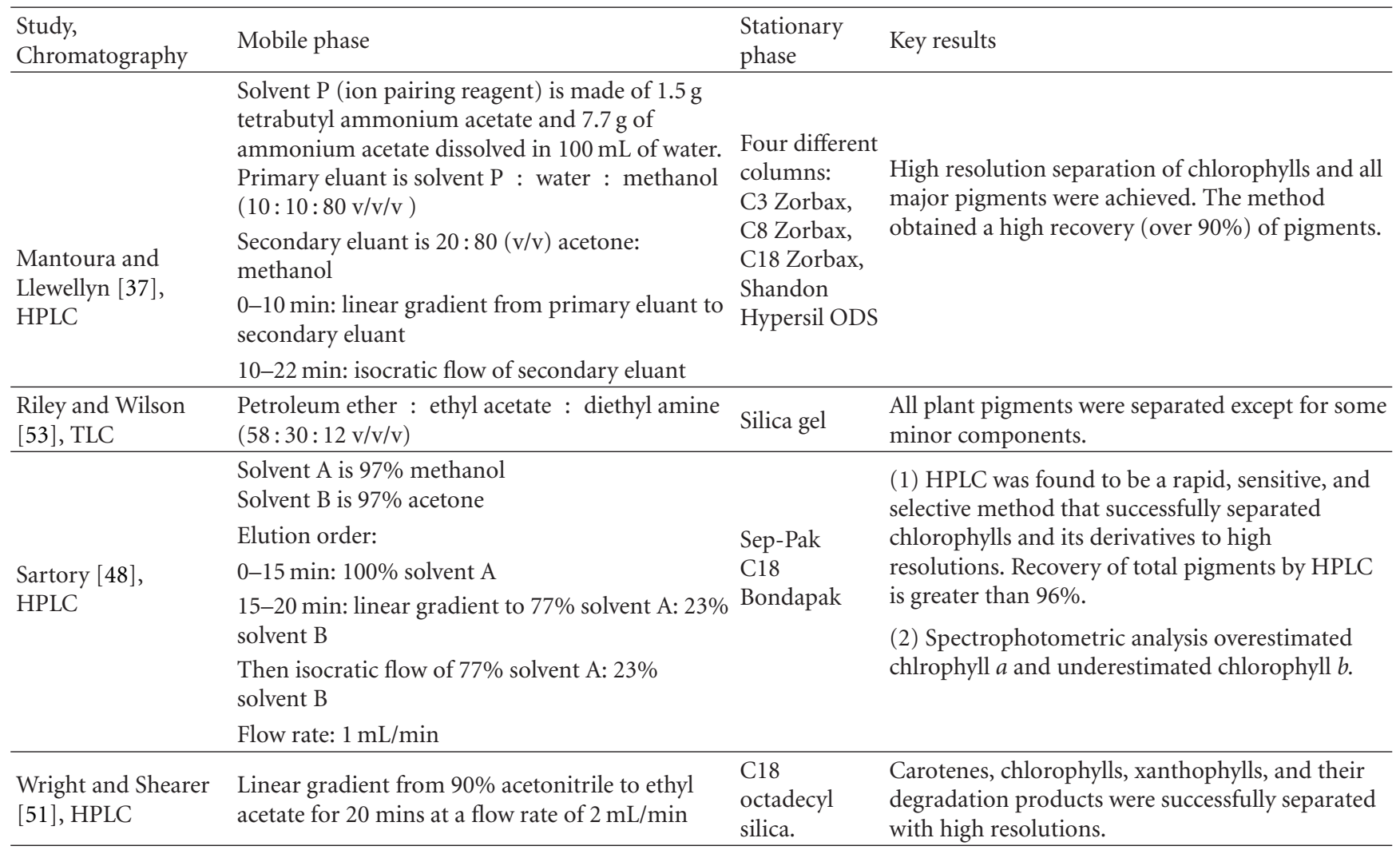

4.2.1. SFE Apparatus. There are two supercritical fluid extraction systems: analytical and preparative. In the analytical system, SFE is directly combined with a chromatographic system. The preparative system is used to extract compounds from samples for example chlorophylls from microalgal biomass. SFE can process either liquid or solid samples.

Figure 5 shows a pilot-scale preparative SFE system. It is made up of a solvent (in this case the solvent is $\mathrm{CO}_{2}$ ) pump, a modifier pump, an extraction cell, valves and two fractionation cells. The extraction cell is for solids whilst packed columns are used for liquids [45]. The microalgal biomass is placed in the extraction cell [42]. The extract is collected and solvent is depressurized in the fractionation cells which are equipped with temperature and pressure controllers. This configuration allows different compounds to be obtained in each fractionation cell based on their differential solubility in the supercritical fluid [45].

4.2.2. Effect of SFE Operating Conditions. The $\mathrm{SCCO}_{2}$ extraction of chlorophyll from microalgae depends on the fluid density which is a function of operating pressure and temperature. Studies have been conducted on $\mathrm{SCCO}_{2}$ extraction of chlorophyll $a$ from at least two microalgal species Nannochloropsis gaditana and Synechococcus sp. Optimum extraction conditions were found to be $60^{\circ} \mathrm{C}$ and 400 bar for Nannochloropsis gaditana and $60^{\circ} \mathrm{C}$ and 500 bar for Synechococcus sp.

At constant temperature, an increase in pressure will increase the fluid density. Even though this will increase the solvating power of the supercritical fluid, it will decrease its diffusion coefficient. The increase in temperature at constant pressure also has a double effect. Increasing temperature raises the vapour pressures of the pigments and hence gives better solubility. However, it will also decrease the density of the supercritical fluid which leads to a lower solvating power. Therefore, the chlorophyll yield on each operating condition will depend on which effect predominates $[43,46]$.

\section{Chlorophyll Fractionation and Purification on Chromatographic Adsorbents}

The traditional method for the quantification of chlorophyll and other pigments in a particular extract is spectrophotometric analysis [34]. The different chlorophyll compounds and other pigments are quantified by measuring the absorbance of a sample at particular wavelengths and using formulated simultaneous equations to calculate the concentrations of particular pigments. It has been found that this method of quantification is often inaccurate as absorption and emission bands of chlorophyll $b$ and other pigments overlap with those of chlorophyll $a$. Chlorophyll degradation products are not detected and studies conducted by different authors provided different simultaneous equations [37, 4750].

In order to overcome the flaws associated with the spectrophotometric analysis, chromatographic techniques are used to fractionate and to quantify chlorophyll and its derivative products. The three types of chromatography 
that have been widely used are paper chromatography, thin layer chromatography (TLC) and high pressure liquid chromatography (HPLC). Paper chromatography was mostly used in the 1950s and 1960s during the early stages of the development of chromatographic techniques. This method was found to effectively separate chlorophyll into its three fractions $(a, b$, and $c)$, pheophytins, carotenes and other derivative products [54]. However, TLC was found to be a preferable technique to paper chromatography due to the ease in quantitatively recovering the pigments from its adsorbents. In paper chromatography, recovery was shown never to exceed $80 \%[49,50,53]$. Additionally, TLC requires less sample, is less tedious, and produces chromatograms with sharper resolutions [52, 53].

Organic adsorbents such as sucrose and cellulose were found to be the most efficient stationary phases for use in two dimensional thin layer chromatography [49]. Riley and Wilson [53] and Lynn Co and Schanderl [52] utilised silica gel as their stationary phase and managed to completely separate all of the plant pigments except for some minor components. However, Jeffrey [49] found that use of silica gel promoted the formation of degradation products and resulted in multiple chlorophyll zones.

HPLC is superior to TLC because it requires even less sample for analysis, is faster and features automatic detection system $[37,51]$. In addition to these, HPLC is more precise and has a higher degree of sensitivity [55]. Reverse phase HPLC is preferred to normal phase as the latter does not separate polar compounds and its polar stationary phase promotes pigment degradation $[37,51]$. An additional drawback of the normal phase HPLC is that it is not compatible with aqueous samples, whereas many of the solvents used for chlorophyll extraction from microalgae are aqueous-based [37]. Several HPLC configurations have been employed, with each providing separation of pigments to varying extents and different resolutions [4]. There are different types of detectors that may be used to measure the concentrations of separated pigments as they exit the column. The most commonly used detectors rely on fluorescence and absorbance analyses. Jeffrey et al. [4] states that fluorescence detection is more sensitive and more selective than absorbance detectors when used to analyze chlorophylls amongst carotenoids. Table 4 summarizes previous studies on chromatographic fractionation of phytoplankton pigments.

\section{Conclusions}

This review article shows that chlorophyll has a wide range of applications due to its colouring effect, tissue growth stimulating effect, antioxidant and antimutagenic properties. Chlorophyll is best extracted from microalgae by supercritical fluid extraction method. High performance liquid chromatography was found to be the most accurate and sensitive technique to fractionate and to quantify chlorophyll along with its derivatives. Furthermore, biological $\mathrm{CO}_{2}$ mitigation with microalgal cultivation helps to minimise the global warming impact. Microalgae seem to be a promising alternative source for chlorophyll.

\section{References}

[1] R. S. Rasmussen, M. T. Morrissey, and L. T. Steve, "Marine biotechnology for production of food ingredients," in Advances in Food and Nutrition Research, pp. 237-292, Academic Press, Boston, Mass, USA, 2007.

[2] A. M. Humphrey, "Chlorophyll," Food Chemistry, vol. 5, no. 1, pp. 57-67, 1980.

[3] Y. Chisti, "Biodiesel from microalgae," Biotechnology Advances, vol. 25, no. 3, pp. 294-306, 2007.

[4] S. W. Jeffrey, R. F. C. Mantoura, and S. W. Wright, Eds., Phytoplankton Pigments in Oceanography: Guidelines to Modern Methods, UNESCO, Paris, Farnce, 1997.

[5] C. Cubas, M. Gloria Lobo, and M. González, "Optimization of the extraction of chlorophylls in green beans (Phaseolus vulgaris L.) by N,N-dimethylformamide using response surface methodology," Journal of Food Composition and Analysis, vol. 21, no. 2, pp. 125-133, 2008.

[6] A. M. Humphrey, "Chlorophyll as a color and functional ingredient," Journal of Food Science, vol. 69, no. 5, pp. 422-425, 2004.

[7] H. Scheer, J. L. William, and M. D. Lane, "Chlorophylls and carotenoids," in Encyclopedia of Biological Chemistry, pp. 430437, Elsevier, New York, NY, USA, 2004.

[8] K. Spears, "Developments in food colourings: the natural alternatives," Trends in Biotechnology, vol. 6, no. 11, pp. 283$288,1988$.

[9] C. F. Timberlake and B. S. Henry, "Plant pigments as natural food colours," Endeavour, vol. 10, no. 1, pp. 31-36, 1986.

[10] L. W. Smith and A. E. Livingston, "Wound healing: an experimental study of water soluble chlorophyll derivatives in conjunction with various antibacterial agents," The American Journal of Surgery, vol. 67, no. 1, pp. 30-39, 1945.

[11] E. B. Carpenter, "Clinical experiences with chlorophyll preparations: with particular reference to chronic osteomyelitis and chronic ulcers," The American Journal of Surgery, vol. 77, no. 2, pp. 167-171, 1949.

[12] B. Horwitz, "Role of chlorophyll in proctology," The American Journal of Surgery, vol. 81, no. 1, pp. 81-84, 1951.

[13] J. B. Cady and W. S. Morgan, "Treatment of chronic ulcers with chlorophyll: review of a series of fifty cases," The American Journal of Surgery, vol. 75, no. 4, pp. 562-569, 1948.

[14] S. L. Goldberg, "The use of water soluble chlorophyll in oral sepsis: an experimental study of 300 cases," The American Journal of Surgery, vol. 62, no. 1, pp. 117-123, 1943.

[15] U. M. Lanfer-Marquez, R. M. C. Barros, and P. Sinnecker, "Antioxidant activity of chlorophylls and their derivatives," Food Research International, vol. 38, no. 8-9, pp. 885-891, 2005.

[16] M. G. Ferruzzi and J. Blakeslee, "Digestion, absorption, and cancer preventative activity of dietary chlorophyll derivatives," Nutrition Research, vol. 27, no. 1, pp. 1-12, 2007.

[17] L. Brennan and P. Owende, "Biofuels from microalgaea review of technologies for production, processing, and extractions of biofuels and co-products," Renewable and Sustainable Energy Reviews, vol. 14, no. 2, pp. 557-577, 2010.

[18] G. A. Florides and P. Christodoulides, "Global warming and carbon dioxide through sciences," Environment International, vol. 35, no. 2, pp. 390-401, 2009.

[19] B. Wang, Y. Li, N. Wu, and C. Q. Lan, " $\mathrm{CO}_{2}$ bio-mitigation using microalgae," Applied Microbiology and Biotechnology, vol. 79, no. 5, pp. 707-718, 2008.

[20] J. R. Benemann, " $\mathrm{CO}_{2}$ mitigation with microalgae systems," Energy Conversion and Management, vol. 38, supplement 1, pp. 475-479, 1997. 
[21] P. Schenk, S. Thomas-Hall, E. Stephens, et al., "Second generation biofuels: high-efficiency microalgae for biodiesel production," BioEnergy Research, vol. 1, no. 1, pp. 20-43, 2008.

[22] E. W. Becker, Microalgae : Biotechnology and Microbiology, Cambridge University Press, Cambridge, UK, 1994.

[23] K. G. Zeiler, D. A. Heacox, S. T. Toon, K. L. Kadam, and L. M. Brown, "The use of microalgae for assimilation and utilization of carbon dioxide from fossil fuel-fired power plant flue gas," Energy Conversion and Management, vol. 36, no. 6-9, pp. 707712, 1995.

[24] M. Packer, "Algal capture of carbon dioxide; biomass generation as a tool for greenhouse gas mitigation with reference to New Zealand energy strategy and policy," Energy Policy, vol. 37, no. 9, pp. 3428-3737, 2009.

[25] J. Masojídek, G Torzillo, J. Sven Erik, and F. Brian, "Mass cultivation of freshwater microalgae," in Encyclopedia of Ecology, pp. 2226-2235, Academic Press, Oxford, UK, 2008.

[26] Z. Cohen, Ed., Chemicals from Microalgae, Taylor \& Francis, London, UK, 1999.

[27] P. Spolaore, C. Joannis-Cassan, E. Duran, and A. Isambert, "Commercial applications of microalgae," Journal of Bioscience and Bioengineering, vol. 101, no. 2, pp. 87-96, 2006.

[28] M. L. Ghirardi, L. Zhang, J. W. Lee, et al., "Microalgae: a green source of renewable H2," Trends in Biotechnology, vol. 18, no. 12, pp. 506-511, 2000.

[29] N. Hanagata, T. Takeuchi, Y. Fukuju, D. J. Barnes, and I. Karube, "Tolerance of microalgae to high $\mathrm{CO}_{2}$ and high temperature," Phytochemistry, vol. 31, no. 10, pp. 3345-3348, 1992.

[30] M. A. Borowitzka, "Commercial production of microalgae: ponds, tanks, tubes and fermenters," Journal of Biotechnology, vol. 70, no. 1-3, pp. 313-321, 1999.

[31] C. U. Ugwu, H. Aoyagi, and H. Uchiyama, "Photobioreactors for mass cultivation of algae," Bioresource Technology, vol. 99, no. 10, pp. 4021-4028, 2008.

[32] G. Marsh, "Small wonders: biomass from algae," Renewable Energy Focus, vol. 9, no. 7, pp. 74-78, 2009.

[33] M. D. Macías-Sánchez, C. Mantell, M. Rodríguez, E. M. de la Ossa, L. M. Lubián, and O. Montero, "Comparison of supercritical fluid and ultrasound-assisted extraction of carotenoids and chlorophyll a from Dunaliella salina," Talanta, vol. 77, no. 3, pp. 948-952, 2009.

[34] D. P. Sartory and J. U. Grobbelaar, "Extraction of chlorophyll a from freshwater phytoplankton for spectrophotometric analysis," Hydrobiologia, vol. 114, no. 3, pp. 177-187, 1984.

[35] R. Schumann, N. Häubner, S. Klausch, and U. Karsten, "Chlorophyll extraction methods for the quantification of green microalgae colonizing building facades," International Biodeterioration and Biodegradation, vol. 55, no. 3, pp. 213222, 2005.

[36] D. Simon and S. Helliwell, "Extraction and quantification of chlorophyll a from freshwater green algae," Water Research, vol. 32, no. 7, pp. 2220-2223, 1998.

[37] R. F. C. Mantoura and C. A. Llewellyn, "The rapid determination of algal chlorophyll and carotenoid pigments and their breakdown products in natural waters by reverse-phase highperformance liquid chromatography," Analytica Chimica Acta, vol. 151, no. 2, pp. 297-314, 1983.

[38] E. Ramsey, Q. Sun, Z. Zhang, C. Zhang, and W. Gou, "Minireview: green sustainable processes using supercritical fluid carbon dioxide," Journal of Environmental Sciences, vol. 21, no. 6, pp. 720-726, 2009.
[39] M. Herrero, J. A. Mendiola, A. Cifuentes, and E. Ibáñez, "Supercritical fluid extraction: recent advances and applications," Journal of Chromatography A, vol. 1217, no. 16, pp. 2495-2511, 2010.

[40] F. Sahena, I. S. M. Zaidul, S. Jinap, et al., "Application of supercritical $\mathrm{CO}_{2}$ in lipid extraction-a review," Journal of Food Engineering, vol. 95, no. 2, pp. 240-253, 2009.

[41] G. Brunner, "Supercritical fluids: technology and application to food processing," Journal of Food Engineering, vol. 67, no. 1-2, pp. 21-33, 2005.

[42] R. L. Mendes, B. P. Nobre, M. T. Cardoso, A. P. Pereira, and A. F. Palavra, "Supercritical carbon dioxide extraction of compounds with pharmaceutical importance from microalgae," Inorganica Chimica Acta, vol. 356, pp. 328-334, 2003.

[43] M. D. Macías-Sánchez, C. Mantell, M. Rodríguez, E. Martínez de La Ossa, L. M. Lubián, and O. Montero, "Supercritical fluid extraction of carotenoids and chlorophyll a from Nannochloropsis gaditana," Journal of Food Engineering, vol. 66, no. 2, pp. 245-251, 2005.

[44] R. L. Mendes, A. D. Reis, and A. F. Palavra, "Supercritical $\mathrm{CO}_{2}$ extraction of $\gamma$-linolenic acid and other lipids from arthrospira (Spirulina)maxima: comparison with organic solvent extraction," Food Chemistry, vol. 99, no. 1, pp. 57-63, 2006.

[45] M. Herrero, A. Cifuentes, and E. Ibañez, "Sub- and supercritical fluid extraction of functional ingredients from different natural sources: plants, food-by-products, algae and microalgae-a review," Food Chemistry, vol. 98, no. 1, pp. 136148, 2006.

[46] M. D. Macías-Sánchez, C. Mantell, M. Rodríguez, E. Martínez de la Ossa, L. M. Lubián, and O. Montero, "Supercritical fluid extraction of carotenoids and chlorophyll a from Synechococcus sp," Journal of Supercritical Fluids, vol. 39, no. 3, pp. 323329, 2007.

[47] J. K. Abaychi and J. P. Riley, "The determination of phytoplankton pigments by high-performance liquid chromatography," Analytica Chimica Acta, vol. 107, pp. 1-11, 1979.

[48] D. P. Sartory, "The determination of algal chlorophyllous pigments by high performance liquid chromatography and spectrophotometry," Water Research, vol. 19, no. 5, pp. 605610, 1985.

[49] S. W. Jeffrey, "Quantitative thin-layer chromatography of chlorophylls and carotenoids from marine algae," Biochimica et Biophysica Acta, vol. 162, no. 2, pp. 271-285, 1968.

[50] J. C. Madgwick, "Chromatographic determination of chlorophylls in algal cultures and phytoplankton,” Deep Sea Research and Oceanographic Abstracts, vol. 13, no. 3, pp. 459-466, 1966.

[51] S. W. Wright and J. D. Shearer, "Rapid extraction and high-performance liquid chromatography of chlorophylls and carotenoids from marine phytoplankton," Journal of Chromatography A, vol. 294, pp. 281-295, 1984.

[52] D. Y. C. Lynn Co and S. H. Schanderl, "Separation of chlorophylls and related plant pigments by two-dimensional thin-layer chromatography," Journal of Chromatography A, vol. 26, pp. 442-448, 1967.

[53] J. P. Riley and T. R. S. Wilson, "Use of thin-layer chromatography for separation and identification of phytoplankton pigments," Journal of the Marine Biological Association of the United Kingdom, vol. 45, no. 3, pp. 583-591, 1965.

[54] S. W. Jeffrey, "Paper-chromatographic separation of chlorophylls and carotenoids from marine algae," Biochemical journal, vol. 80, no. 2, pp. 336-342, 1961.

[55] W. T. Shoaf, "Rapid method for the separation of chlorophylls a and b by high-pressure liquid chromatography," Journal of Chromatography A, vol. 152, no. 1, pp. 247-249, 1978. 

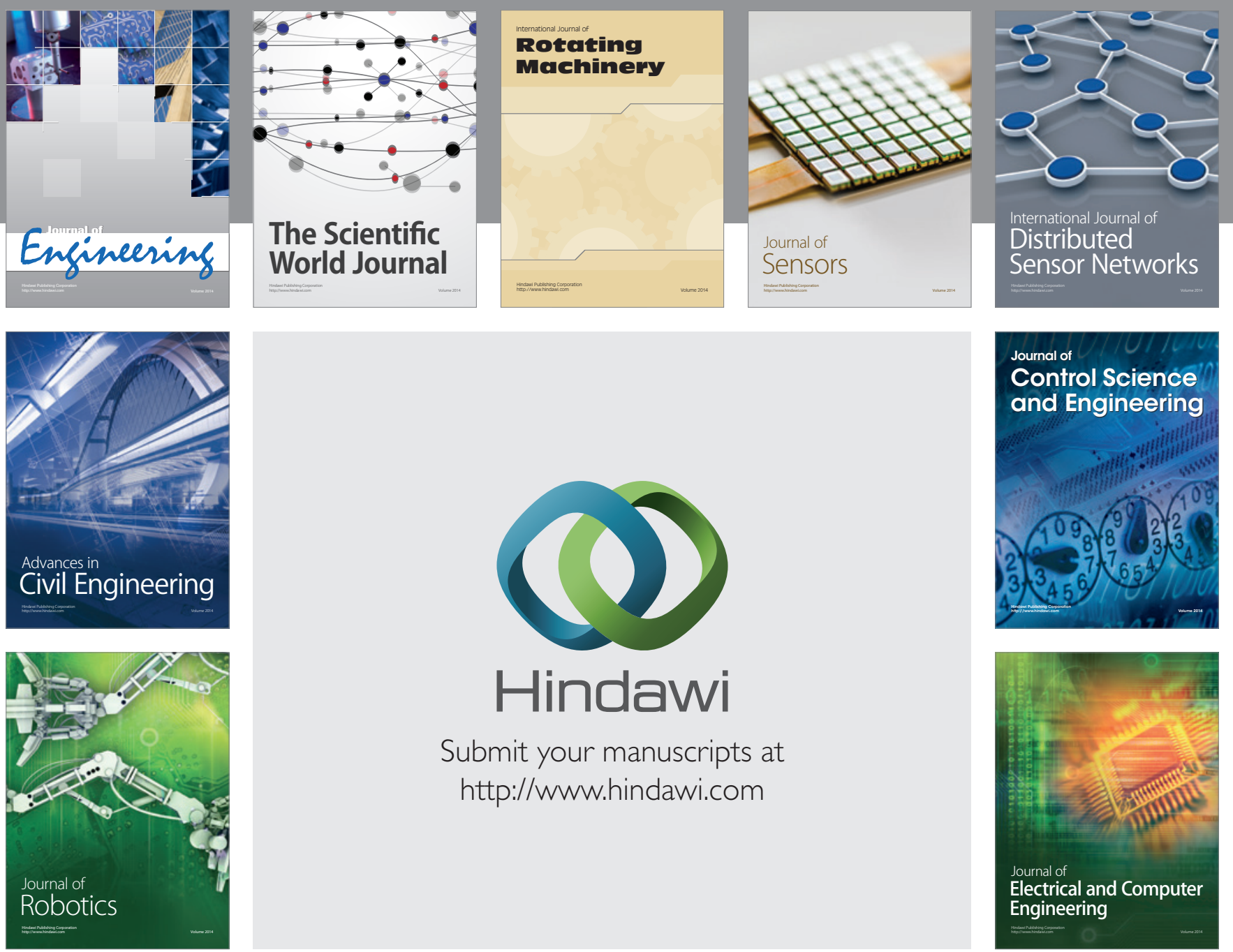

Submit your manuscripts at

http://www.hindawi.com
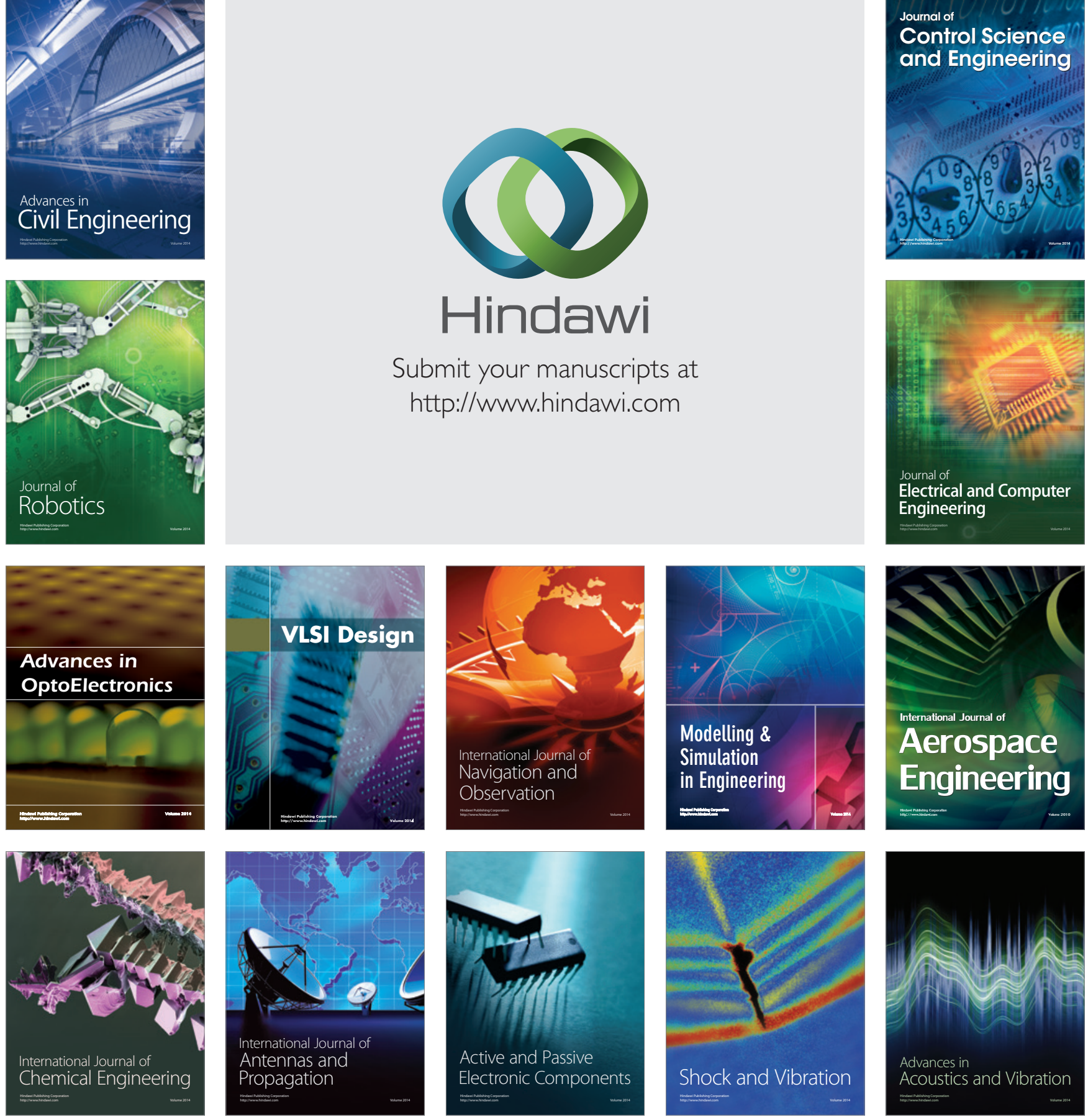